\title{
Scar Prevention in Peripheral Nerve Surgery
}

\author{
FRASER W. SAUNDERS
}

\begin{abstract}
SUMMARY: Constriction of a peripheral nerve may precipitate a primary problem or prevent recovery from a pre-existing one. Any surgical technique to minimize subsequent constrictive scar formation would be advantageous. In this study, using rat femoral nerves, various modes of protection were evaluated. Wrapping the nerve with free fat seemed to offer the best prophylaxis.
\end{abstract}

RESUME: La constriction d'un nerf périphérique peut précipiter un problème primaire ou empêcher le recouvrement d'un problème pré-existant. Toute technique chirurgicale qui minimiserait la formation de cicatrice constrictive serait avantageuse. Dans la présente étude nous avons évalué plusieurs types de protection en employant comme modèle les nerfs fémoraux du rat. Il semble que le fait d'envelopper le nerf avec des graisses libres présente la meilleure prophylaxie.

From the Department of Surgery (Neurosurgery), Queen's University, Kingston, Ontario.

Reprint requests to Dr. F.W. Saunders, Division of Neurological Surgery. Queen's University, Douglas III. Kingston General Hospital, Kingston, Ontario, Canada K7L 2 V7.

\section{INTRODUCTION}

Peripheral nerves are affected adversely by constriction. Many procedures, such as the carpal tunnel release and the ulnar nerve transposition, are based on this pathogenesis. Constriction has been documented to cause anatomic alterations (Spinner, 1978), a decreased ability of axons to conduct an action potential (Brown et al, 1976; Rudge et al, 1974), and a decreased velocity of axoplasmic flow (Weiss et al, 1962). The release of the constriction frequently results in clinical improvement (Tanzer, 1959).

It seems to follow that secondary constriction of a nerve by scar may lead to delayed recovery or subsequent deterioration. It has been reported that secondary scar has adversely affected the result after peripheral nerve injury and surgical procedures (Nulsen and Kline, 1973). It therefore would seem advantageous to adopt any surgical technique that would keep scar formation to a minimum.

\section{MATERIALS AND METHODS}

Adult Spraque-Dawley rats were used as the experimental animal. The femoral nerves were exposed bilaterally, separated from the adjacent vascular bundle, mobilized and then implanted in the quadriceps muscle bed. The groove in the muscle was oversewn to keep the nerve in place. On the control side no protection was offered to the nerve. On the experimental side the nerves were protected with Gelfoam, steroid soaked Gelfoam, free fat grafts, polyethylene sheaths and preformed fibrous tracts. In each series five rats were used. The rats were sacrificed three months after implantation of the nerves, the quadriceps muscles removed en bloc and the assessment of perineural scarring was done by histologic section. Multiple sections were taken from each rat and the results were consistent for each substance tested.

\section{RESULTS}

The control specimens in each animal showed perineural invasion by scar tissue. (Fig. 1). The application of Gelfoam or steroid soaked Gelfoam did not seem to offer any advantage. (Fig. 2). Encasing the nerve in polyethylene sheaths seemed to stimulate scar formation from the nerve itself. (Fig. 3). Placing the nerve in a preformed fibrous tract resulted in sections that looked similar to the controls. (Fig. 4). Free fat grafts appeared to offer the only consistent benefit in preventing perineural scar formation. (Fig. 5).

\section{DISCUSSION}

These experiments seem to imply that wrapping a nerve in free fat offers some protection to scar proliferation. This is consistent with the experiments directed toward the lumbar spine. (Keller et al, 1978; Barbera et al, 1978). The mechanism by which fat is efficacious has not been elucidated.

It is well established that constrictive scar tissue may be detrimental to nerve function. It seems that wrapping the nerve with fat taken from the subcutaneous tissue may offer a simple means of reducing this problem.

\section{ACKNOWLEDGEMENTS}

This work was done under the support of a Health Research Scientist Grant from the Ontario Ministry of Health.

I would like to thank Mr. Ken Green for his laboratory assistance and Dr. S. Nag for her help in the slide preparation and interpretation. 


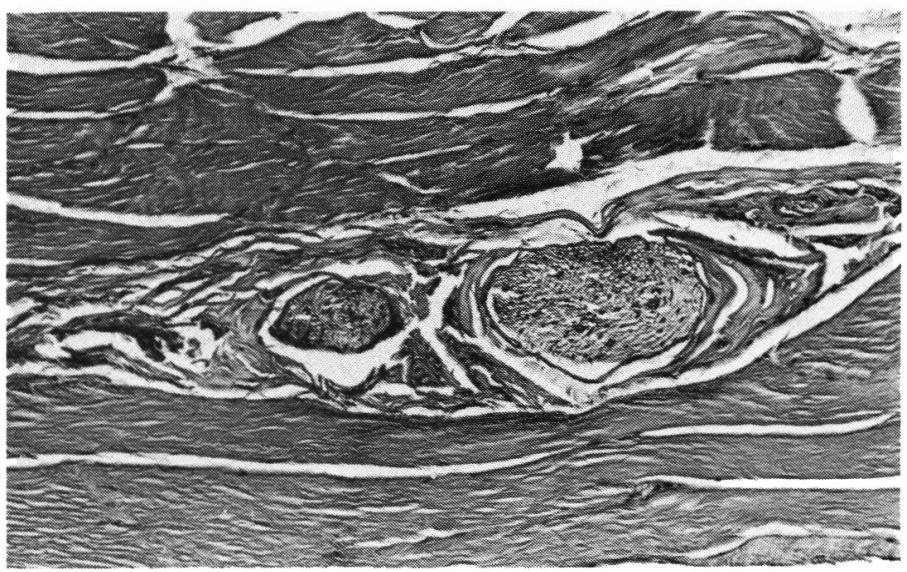

Figure $l$ - Control specimens show encasement of the nerve by scar tissue. $(\mathrm{X} 80)$

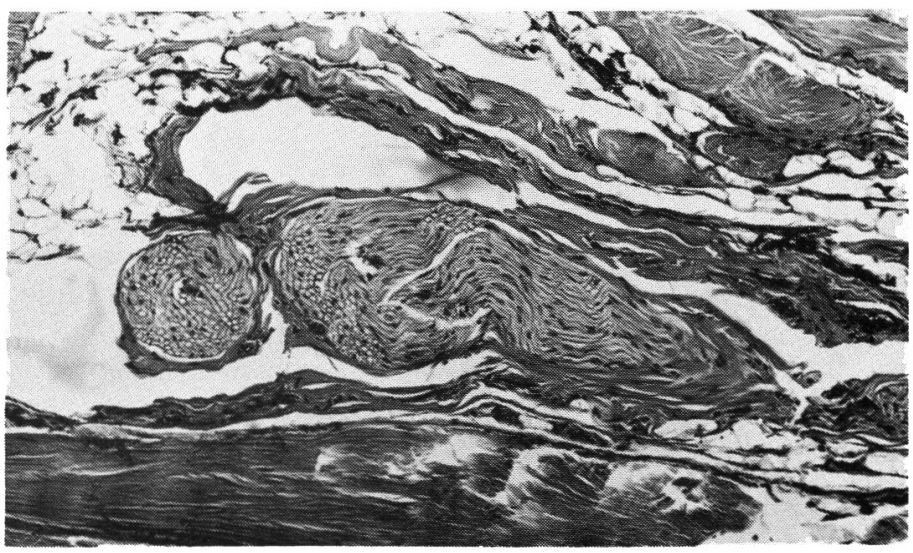

Figure 2 - Gelfoam and steroid soaked Gelfoam did not inhibit the perineural scar tissue formation. (X80)

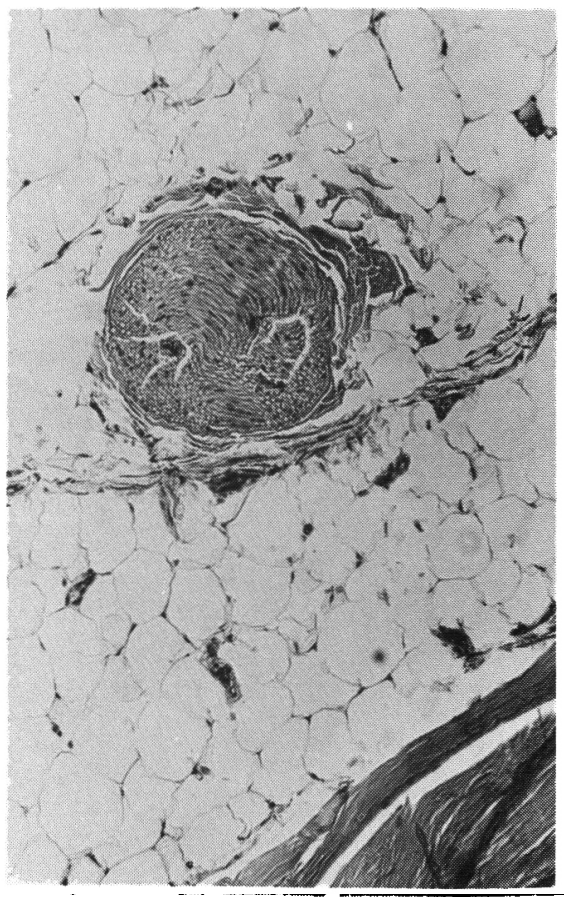

Figure 5 - Surrounding the nerve in free fat appears to significantly decrease the amount of scar tissue. (X80)

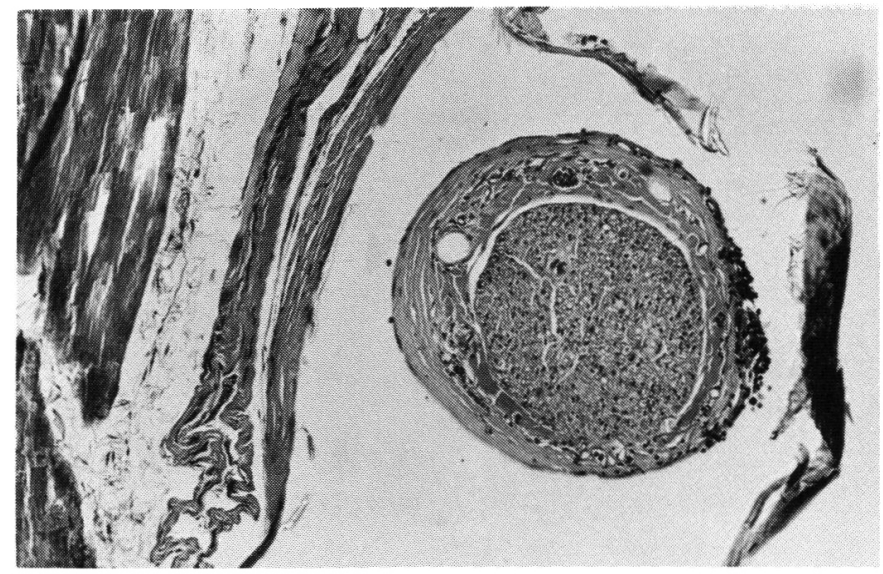

Figure 3 - Polyethylene seemed to stimulate scar tissue from the nerve itself. $(X 80)$

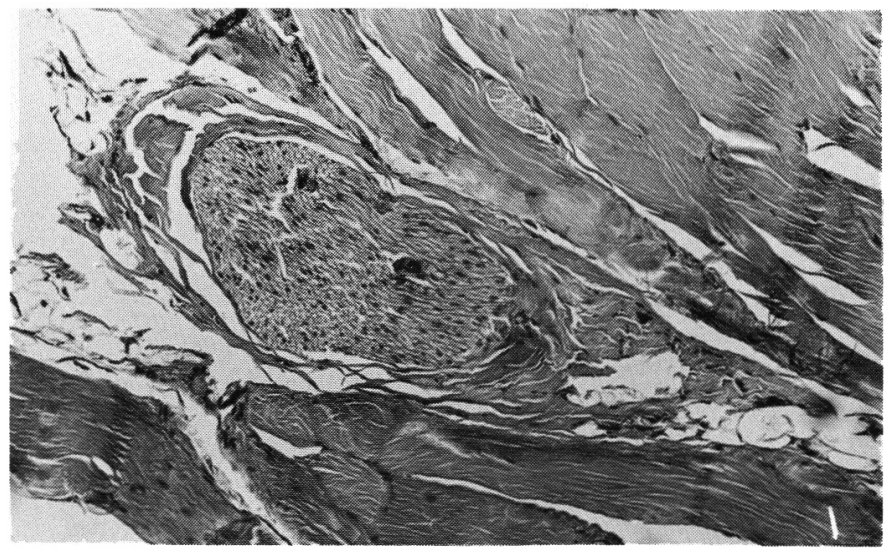

Figure 4 - Encasing the nerve in a preformed fibrous tract did not alter the scar tissue formation. (X80)

\section{REFERENCES}

BARBERÁ, J., GONZALEZ, J., ESQUERDO, J., BROSETA, J., BARCIA-SALORIO, J.L. (1978). Prophylaxis of the laminect omy membrane. Journal of Neurosurgery. 49: 419-424.

BROWN, W.F., FERGUSON, G.G., JONES, M.W., YATES, S.K. (1976). The location of conduction abnormalities in human entrapment neuropathies. The Canadian Journal of Neurologic Sciences. 112: 111-122.

KELLER, J.T., DUNSKER, S.B., McWHORTER, J.M., ONGKIKO, C.M., SAUNDERS, M.C., MAYFIELD, F.H. (1978). The fate of autogenous grafts to the spinal dura. Journal of Neurosurgery. 49: 412-418.

NULSEN, F.E., KLINE, D.G. (1973). Acute injuries of peripheral nerves. In: Neurological Surgery, J.R. Youmans, Eds., Toronto;
W.B. Saunders Company. Vol. II, pp 10891140.

RUDGE, P., OCHOA, J., GILLIATT, R.W. (1974). Acute peripheral nerve compression in the baboon. Journal of Neurologic Sciences. 23: 403-420.

SPINNER, M. (1978). Current concepts in the management of nerve compression lesions. In: Injuries to the major branches of peripheral nerves of the forearm. Toronto: W.B. Saunders Company. Chapter IV, pp 26-39.

TANZER, R.C. (1959). The carpal tunnel syndrome: A clinical and anatomic study. Journal of Bone and Joint Surgery. 41-A 626-634.

WEISS, P., TAYloR, A.C., PILlai, P.A. (1962). The nerve fiber as a system in continuous flow: microcinematographic and electromicroscopic demonstration. Science. 136: 330 (abstract). 